\title{
Crack Behaviour of Self-Compacting Concrete (SCC) Beams Containing Eggshell in Flexural
}

\author{
Mohd Raizamzamani Md Zain*, Oh Chai Lian', Lee Siong Wee², Norrul Azmi \\ Yahya $^{1}$ and Anizahyati Alisibramulisi ${ }^{1}$
}

${ }^{1}$ School of Civil Engineering, College of Engineering, Universiti Teknologi MARA, 40450, Shah Alam, Selangor Darul Ehsan, Malaysia

${ }^{2}$ School of Civil Engineering, College of Engineering, Universiti Teknologi MARA Johor, Pasir Gudang Campus, 81750, Masai, Johor, Malaysia

\begin{abstract}
Rapid innovations in the ever-expanding area of the construction sector have turned into such a self-compacting concrete investigation (SCC). As a result of the effect on financial and ecological values, the importance of such innovation is expanding quickly. Many researchers have improved the efficiency of the present SCC using industrial materials. Pertinently, substituting cement with surplus material in the manufacture of concrete is environmentally sustainable. Eggshell has become one of the possible alternatives for cementitious material because it encompasses a compound of calcium. Such endeavour is primarily driven by the restriction of landfill sites and the desire to decrease the warming effect. This study describes the failure behaviour and cracks characteristics of SCC beams comprising eggshells under flexural assessment. In order to measure its compressive strength, an SCC mixture encompassing eggshells was developed and evaluated. The

ARTICLE INFO

Article history:

Received: 26 May 2021

Accepted: 4 August 2021

Published: 28 October 2021

DOI: https://doi.org/10.47836/pjst.29.4.44

E-mail addresses:

raizam@uitm.edu.my (Mohd Raizamzamani Md Zain)

chailian@uitm.edu.my (Oh Chai Lian)

leesiongwee@uitm.edu.my (Lee Siong Wee)

norrulazmi@uitm.edu.my (Norrul Azmi Yahya)

aniza659@uitm.edu.my (Anizahyati Alisibramulisi)

*Corresponding author

ultimate flexural strength and propagation of cracks were discussed for SCC beams tested under flexural using a various $a / d$ (shear span to an effective depth) ratio. The SCC beams crack widths were also validated with Eurocode2. When loads are placed close to supports (lower $a / d$ ratio), the results show that SCC beams can sustain a higher load with improved deflection control. The finding among all SCC beam assessments
\end{abstract}

ISSN: 0128-7680

e-ISSN: 2231-8526 
unveiled that the initial value of experimental crack width was significantly less than the $0.3 \mathrm{~mm}$ maximum crack control limit delineated by Eurocode2 (EN 1992-1-1, 2004). Various kinds of crack characteristics have also been detected in SCC beam specimens marked as flexural, shear, and combination of shear-flexural cracks.

Keywords: Crack patterns, eggshell, flexural strength, SCC beams, self-compacting concrete

\section{INTRODUCTION}

Concrete has figured prominently and is also the most widely used construction material for hundreds of years, particularly in building applications. Now, a considerable effort is being made to improvise the properties of concrete, whether through its shear and flexural strength, tensile strength, compressive strength, aesthetic appearance or compaction properties. Nowadays, numerous types of recycled materials have been used in the building industry. Waste materials, including fly ash, bottom ash, sludge, palm oil and eggshells, have been used to manufacture concrete and have become a common alternative to wellfunctioning concrete technology. These helped increase profits in addition to reducing the number of waste products. Furthermore, incorporating mineral admixtures in the concrete mixture has resulted in SCC produced cheaply while not undermining the other features of the concrete concurrently.

Self-compacting concrete (SCC) could also be defined as concrete that does not necessitate compaction and spreads through its weight even without bleeding and segregation to enable greater compactness and placement. SCC had first been initially developed in 1983 to address the resilience of concrete buildings in Japan due to the deficiency of qualified workers (Okamura \& Ouchi, 2003; Akinpelu et al., 2019; Siddique, 2011). Adequate compaction via qualified labour is necessary to create long-lasting concrete buildings. Nevertheless, the steady drop in the number of qualified construction workers has resulted in a corresponding decline in the quality of construction activities. Therefore, the utilisation of SCC, which could be compacted into every section of a formwork, became one alternative for achieving long-lasting concrete buildings, regardless of the quality of construction activities. SCC has numerous benefits, including the avoidance of expensive labour activities, which improves the construction site's productivity from the contractor's perspective. Furthermore, as vibration is excluded during casting processes, workers have few intensive tasks with substantially less noise. It is indeed a revolutionary concrete capable of flowing under its weight, entirely covering the formwork and thus maximising compaction (Okamura \& Ouchi, 2003; Akinpelu et al., 2019).

However, the only concern with self-compacting concrete was its cost. It contributes to the massive amount of Portland cement and preserving the needed freshness and durability of the SCC. As demonstrates by EPG (2015), Challagalli and Hiremath (2017), Dinakar 
et al. (2008), Dinakar et al. (2013), Safi et al. (2013), Siddique (2011), and Faraj et al. (2020), the approach to attain the performance and intended freshness of the SCC via the utilisation of mineral mixtures such as fly ash, silica fumes, plastic waste, tyre rubber waste and fibre, which finely granulated and blended into a concrete mixture. It indicates that it is possible to obtain a multitude of SCC strengths utilising waste materials. SCC typically uses lesser volumes and smaller amounts of coarse aggregates relative to conventional concrete, which greatly influences the mechanical properties (Yerramala, 2014; Oh et al., 2019; Olowofoyeku et al., 2019).

Furthermore, apart from examining the rheological features of SCC incorporating waste materials, many researchers also have explored the hardened properties, shear and flexural characteristics of SCC (Domone, 2007; Tang et al., 2016; Panda \& Bal, 2013; Karthick et al., 2014; Parthasarathi et al., 2017). Domone (2007) reviewed and correlated over 70 research findings on the hardened features of SCC in order to generate comparative analysis with the characteristics of similar strength of ordinarily or normally vibrated concrete (NVC). Tang et al. (2016) and Panda and Bal (2013) evaluated the hardened properties of SCCs comprising recycled coarse aggregates. Concrete reuse such as recycled coarse aggregates not just preserves virgin resources of concrete but also decreases environmental impacts and directly eliminates carbon dioxide from the atmosphere. Nevertheless, according to Panda and Bal (2013), the results of split tensile, compressive and flexural strengths of the SCC encompassing the natural aggregate is more than the SCC comprising the recycled concrete aggregate (RCA). As a result, multiple substitutes were adopted, including agricultural by-products such as eggshells as a partial substitute for sand or cement.

Karthick et al. (2014) performed an experimental study to evaluate the influence of eggshells as a partial substitution of sand in concrete, having undergone split tensile, compressive and flexural strength tests. The researchers discovered that the concrete compressive strength fulfilled the desired strength with an optimal proportion of 20 per cent of eggshells as a substitute for sand in the mixture of concrete. The use of eggshell and silica fume as partial substitutes of cement was also being investigated by Parthasarathi et al. (2017). The tests demonstrated that the inclusion of waste products such as silica fume improves strength. However, the substitution of eggshell powder (ESP) seems more cost-effective and produces the predicted strength. This research investigation has shown that the ESP alone can serve as a substitute for cement, enhancing the concrete strength parameters and reducing the need for cement.

Numerous studies have been carried out to examine the behaviour of self-compacting concrete beams (Sonebi et al., 2003; Tošić et al., 2016; Boel et al., 2010; Hassan et al., 2008; Mahmod et al., 2018; Sharifi, 2012; Harkouss \& Hamad, 2015; Odaa et al., 2021). In terms of shear and flexural characteristics, Tošić et al. (2016) provided a comprehensive study on shear and flexural characteristics of beams utilising RCA with and without 
stirrup. The results have shown that the shear and flexural strength of the concrete beam specimens without stirrups seem to be in close agreement with Eurocode2 (EN 1992-1-1, 2004). Boel et al. (2010) explored the shear strength of normal vibrated and SCC beam samples. The aggregate content in the SCC sample was 43 per cent lower. The findings demonstrate that the shear capacity of a normal vibrated concrete (NVC) beam sample is significantly higher than that of an SCC beam sample, which could be attributed to higher aggregate interlock triggered by higher coarse aggregates (Boel et al., 2010). Hassan et al. (2008) also investigated the strength properties (shear capacity) and cracking behaviour patterns of full-scale concrete beams of SCC and NVC. Compared to NVC beams, SCC beam samples had a reduced maximum shear strength due to fewer coarse aggregates in SCC beams than in NVC samples.

Mahmod et al. (2018) examined the flexural strength of 14 reinforced SCC beams comprising varying percentages of steel fibre. The results have been compared to the international standard (ACI CODE-318-14, 2014). Flexural strength in beams has been found to upsurge with increasing compressive strength of concrete, the ratio of longitudinal steel rebar, and fibre content. Sharifi (2012) investigated and compared the mechanical characteristics of reinforced SCC beams to the anticipated provisions code for NVC. The findings suggest that theoretical estimations for reinforced concrete beams are reliable enough to be applied in assessing SCC beam capacities (Sharifi, 2012). Although a great deal of work was undertaken on reinforced concrete beams containing additives or waste, specific information of the failure behaviour and crack patterns of SCC beams containing eggshells in flexural are minimal, and the subject remains open.

Based on the preceding literature search, the ESP has demonstrated to be an excellent catalyst for cement-bound material due to several advantages, including being rich in calcium composition, quite similar to the limestone used to make cement. The eggshell thus becomes beneficial for lessening the need for cement in concrete casting and seems to be useful for recycling waste materials. Thereby, in consideration of these and taking into account the benefit of the use of ESP in the manufacture of SCC beams, a series of laboratory testing were employed to examine the flexural strength and analyse the characteristics of the crack of SCC beams encompassing ESP under bending assessment.

\section{METHOD}

For this research, an experimental study was conducted on SCC beams comprising eggshells as a cement substitute. The preparation of the production of the SCC beams was separated into two (2) stages. The first stage necessitates establishing the SCC mixture. The second stage entails the testing process of SCC beams under flexural to evaluate their structural strengths and assesscrack patterns, as illustrated in Figure 1. Particulars upon this preparation of specimens, the set-up of the test and the laboratory tests were presented and explained in the subsequent sub-topics. 


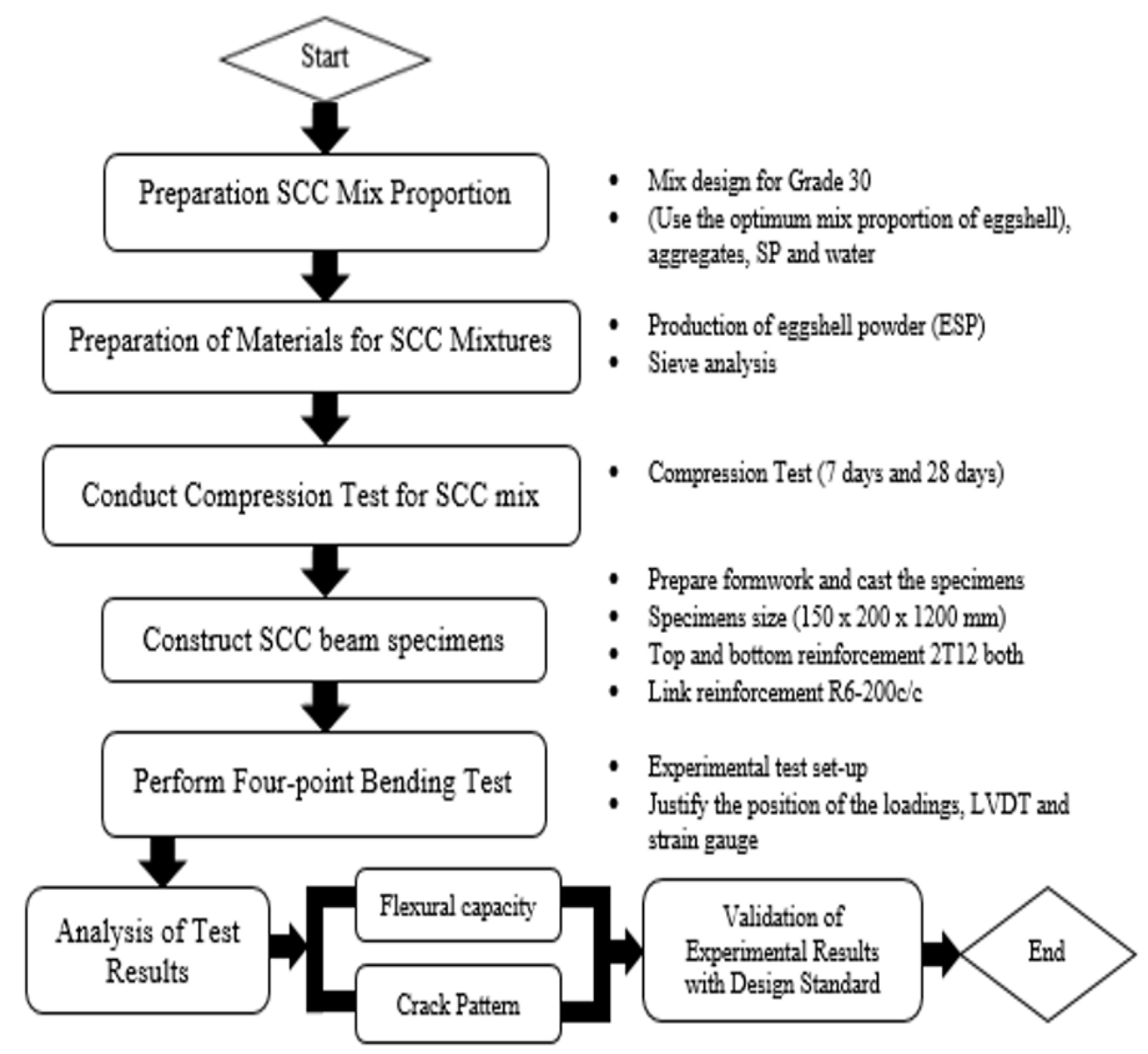

Figure 1. A research flow chart that summarises the process of preparing and testing beam specimens

\section{Materials and Mixture Proportions}

The key materials involved in this laboratory study encompass Portland cement, coarse aggregate, water, eggshell, fine aggregate and superplasticiser, as depicted in Figure 2. In this SCC mixture, the ESP and ordinary Portland cement have been employed as binders. Also, the coarse aggregate (CA) size used was less than $10 \mathrm{~mm}$ for the mixture of SCC, as anticipated in the mix design. In order to accomplish the preferred aggregate size, it was sieved before being employed in the concrete mix. While, for fine aggregates (FA), the natural sand, with the size around $0.3 \mathrm{~mm}$ to $0.8 \mathrm{~mm}$, was used. The ratio of finecoarse aggregates and water-cement was 0.6 and 0.4, respectively. Besides that, type of superplasticiser (SP) used was BASF MasterGlenium8784 obtained from BASF (Malaysia) Sdn Bhd situated in Selangor, as shown in Figure 2(d). The quantity of superplasticiser applied to the mixture was $1 \%$ of the amount of cement content. Besides that, eggshells 
gathered from different sources were crushed via grinders and sieved by sieving machines to attain $0.6 \mu \mathrm{m}$ of fine eggshell powder (ESP), as displayed in Figure 2(e).

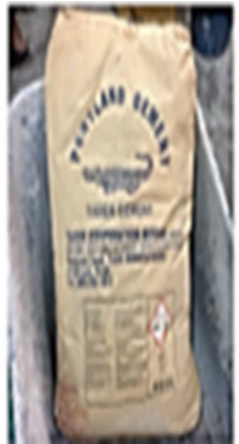

(a) Cement

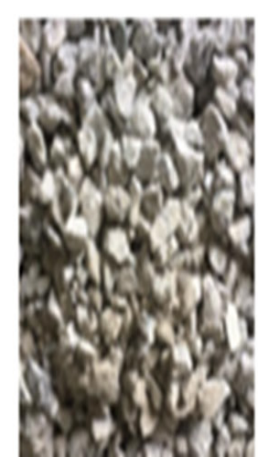

(b) $\mathrm{CA}$

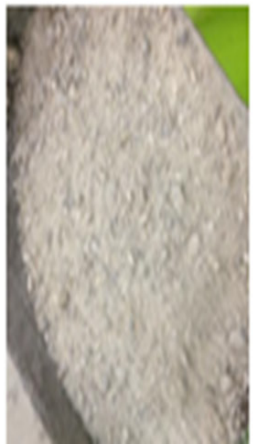

(c) FA

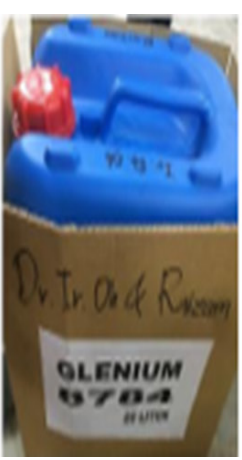

(d) SP

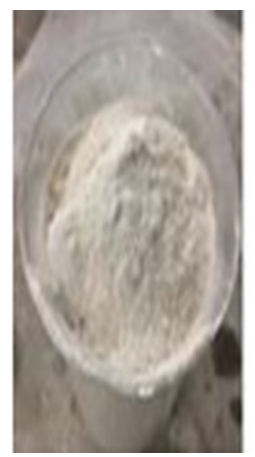

(e) ESP

Figure 2. SCC constituent materials

The mixing design process was undertaken in compliance with BS 1881-125:2013 (2013) (standard design procedure). The number of constituent materials employed for all SCC mixtures encompassing $0.6 \mu \mathrm{m}$ eggshell as cement substitute is indicated in Table 1. Meanwhile, the chemical properties of cement and eggshell are demonstrated in Table 2.

Table 1

Quantity of constituent materials used for the SCC mixture

\begin{tabular}{cccccc}
\hline $\begin{array}{c}\text { Cement } \\
\left(\mathrm{kg} / \mathrm{m}^{3}\right)\end{array}$ & $\begin{array}{c}\text { FA } \\
\left(\mathrm{kg} / \mathrm{m}^{3}\right)\end{array}$ & $\begin{array}{c}\mathrm{CA} \\
\left(\mathrm{kg} / \mathrm{m}^{3}\right)\end{array}$ & $\begin{array}{c}\text { Water } \\
\left(\text { litre } / \mathrm{m}^{3}\right)\end{array}$ & $\begin{array}{c}\mathrm{SP} \\
\left(\text { litre } / \mathrm{kg} / \mathrm{m}^{3}\right)\end{array}$ & $\begin{array}{c}\mathrm{ESP} \\
\left(\mathrm{kg} / \mathrm{m}^{3}\right)\end{array}$ \\
\hline 463.5 & 644 & 966 & 215 & 5.15 & 51.5 \\
\hline
\end{tabular}

Table 2

Elemental composition of cement and eggshell powder

\begin{tabular}{|c|c|c|c|}
\hline \multicolumn{2}{|c|}{ Elemental composition of cement } & \multicolumn{2}{|c|}{ Elemental composition of eggshell powder } \\
\hline Compositions & Percentage & Compositions & Percentage $(\%)$ \\
\hline $\mathrm{CaO}$ & 64.64 & $\mathrm{CaO}$ & 71.77 \\
\hline $\mathrm{SiO}_{2}$ & 21.28 & $\mathrm{SiO}_{2}$ & 16.28 \\
\hline $\mathrm{Fe}_{2} \mathrm{O}_{3}$ & 3.36 & $\mathrm{Fe}_{2} \mathrm{O}_{3}$ & 4.37 \\
\hline $\mathrm{Al}_{2} \mathrm{O}_{3}$ & 5.60 & $\mathrm{Al}_{2} \mathrm{O}_{3}$ & 2.92 \\
\hline $\mathrm{MgO}$ & 2.06 & $\mathrm{SO}_{3}$ & 2.60 \\
\hline $\mathrm{SO}_{3}$ & 2.14 & & \\
\hline Loss on Ignition & 0.64 & & \\
\hline Insoluble Residue & 0.22 & & \\
\hline Total Alkalis & 0.05 & & \\
\hline
\end{tabular}




\section{Details of Test for SCC Beam Specimens}

In this study, SCC cubes and SCC beam specimens were prepared and tested for failure. A total of six SCC cubes $(150 \mathrm{~mm} \times 150 \mathrm{~mm}$ in cross-sectional dimension with $150 \mathrm{~mm}$ in height) have been cast and tested for assessing their compressive strength $\left(f_{c u}\right)$. In addition, SCC cube specimens were checked and tested for failure under axially compression loading after 7 days and 28 days of curing age to examine the hardened state of the mixture as shown in Figure 3, and the outcome is presented in Figure 4.

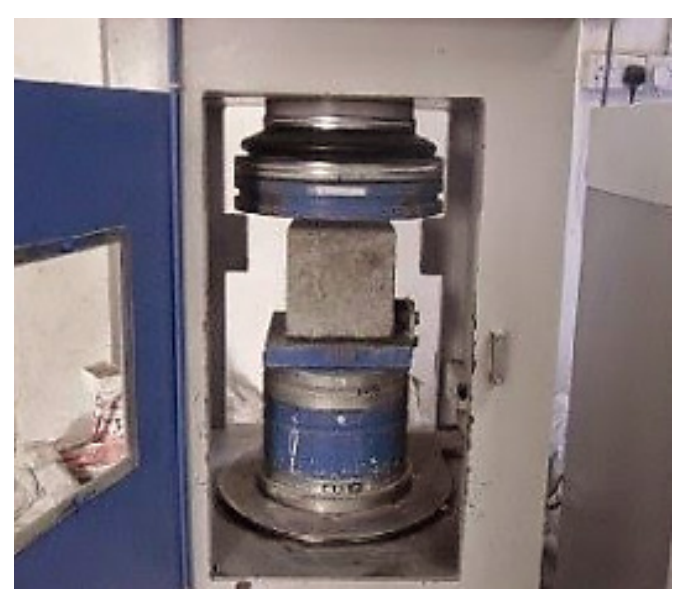

Figure 3. SCC cube under axially compressive loading

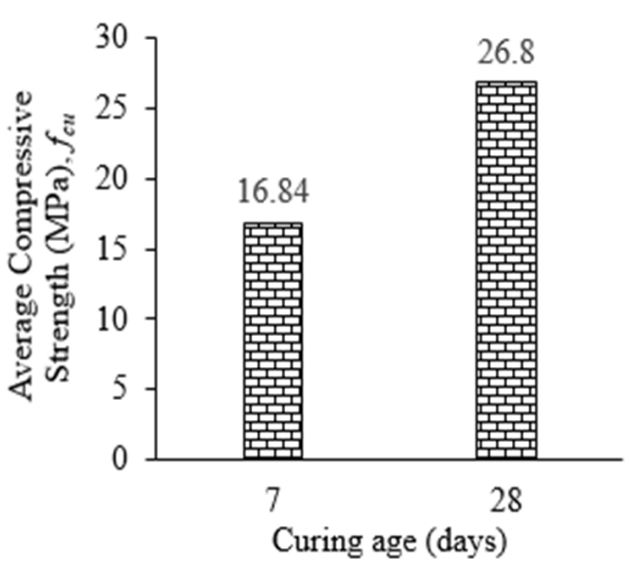

Figure 4. Hardened properties of the SCC mixture

Three (3) numbers of SCC beam specimens (150mm x 200mm in cross-section and $1200 \mathrm{~mm}$ length) comprising ESP labelled as SCCBESP1.0, SCCBESP2.0 and SCCBESP3.0 were constructed with $10 \mathrm{~mm}$ diameter of both upper and lower rebars. The nominal cover and effective depth of the SCC beams are $25 \mathrm{~mm}$ and $160 \mathrm{~mm}$, respectively. Its high yield deformed longitudinal rebar, and the link of $6 \mathrm{~mm}$ diameter have the characteristics strength of $460 \mathrm{~N} / \mathrm{mm}^{2}$ and $250 \mathrm{~N} / \mathrm{mm}^{2}$, respectively. The link was installed at $200 \mathrm{~mm}$ spacing across the beam. All specimens of SCC beams were cast and tested for failure under flexural test after 28 days of their designated age.

\section{Instrumentation, Procedure and Test Set-up}

Under flexural inspection, all specimens of the SCC beam delineated as SCCBESP1.0, SCCBESP1.5 and SCCESP2.0 were tested up to failure utilising Universal Testing Machine (UTM). Also, every SCC beam specimen has been tested for failure under bending test (4-point flexural test) at $a / d$ (shear span to effective depth) ratio of $1.0(\mathrm{a}=160 \mathrm{~mm}), 1.5$ $(\mathrm{a}=240 \mathrm{~mm})$ and $2.0(\mathrm{a}=320 \mathrm{~mm})$, respectively, as depicted in Figure 5. The values of varying shear spans $(a)$ were $320 \mathrm{~mm}, 240 \mathrm{~mm}$ and $160 \mathrm{~mm}$. Linear variable differential 
transformers (LVDTs) were positioned at one-third of the beam span from each support (lower part of the beams) and at the central part of the beam soffit to evaluate cross-head deformation under the applied load. The load applied was increased continuously till failure at a displacement rate of $0.01 \mathrm{~mm} / \mathrm{s}$.

All measurements were recorded automatically via an automated data acquisition system. The formation of cracks was observed and marked as shown in Figure 6(a). Assessment of the behaviour of cracks was visually conducted, whereas the crack patterns and propagation were hand-marked. Optical magnification X10 microscope (reading up to $0.02 \mathrm{~mm}$ ) were used to measure the crack widths, as shown in Figure 6(b). Formation and spread of both shear and flexural cracks were recorded toward respectively applied loads.

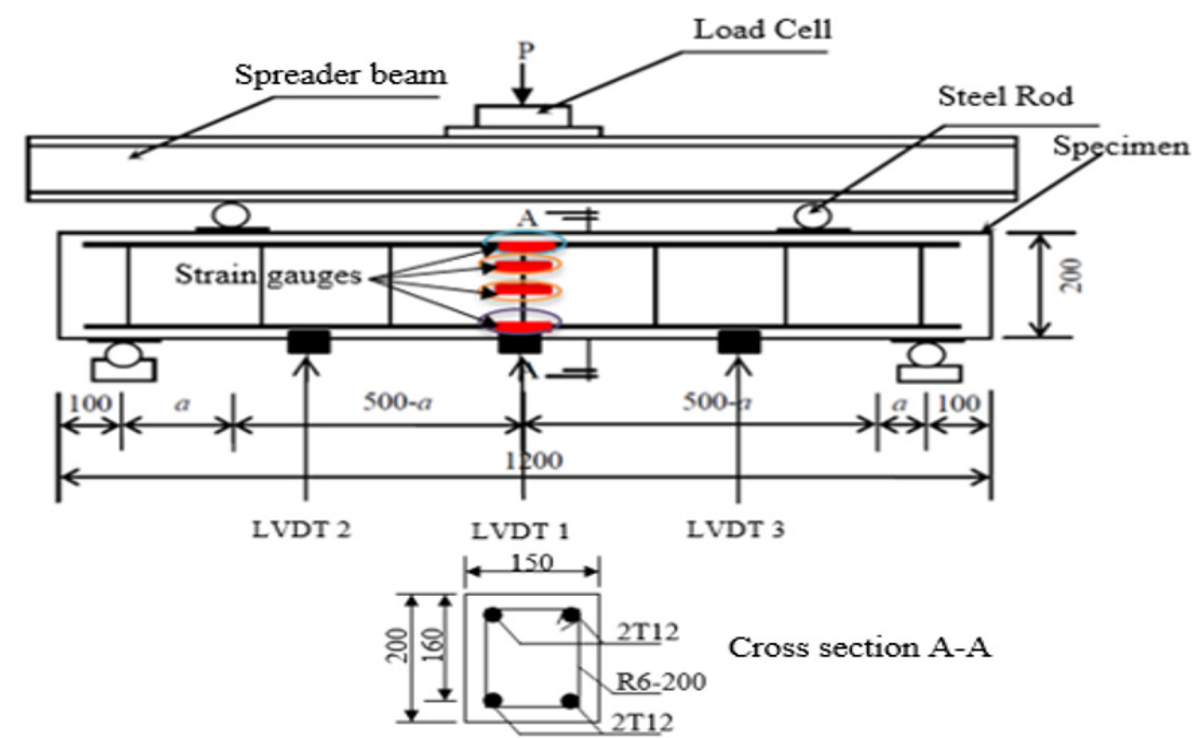

(a) Load test schematic diagram (beam reinforcement arrangement)

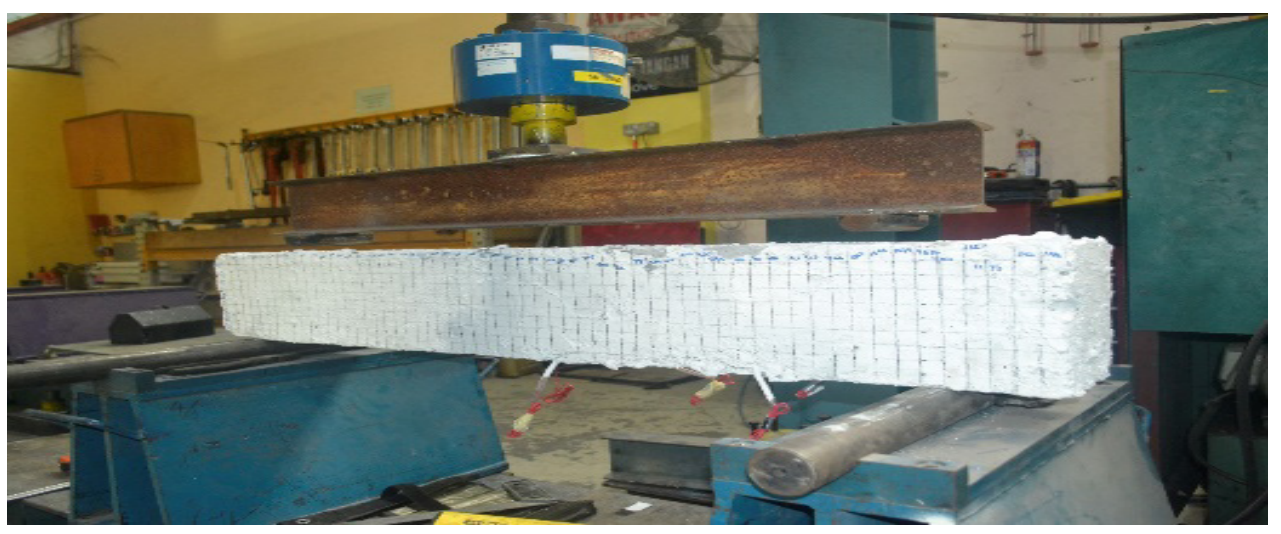

(b) Universal Testing Machine (UTM) was used to conduct the beam load test Figure 5. Experimental set-up of beam specimen and load test 


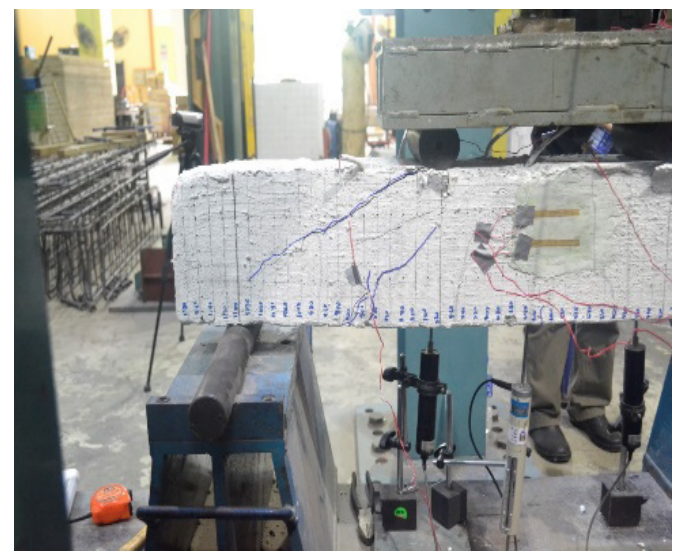

(a) Cracks formation on SCC beam

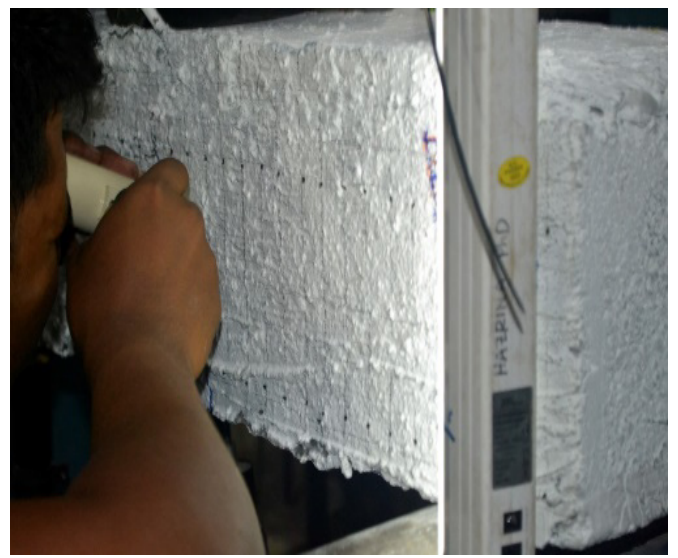

(b) Measurement of crack widths via optical magnification X10 microscope

Figure 6. Observation and measurement of cracks on SCC beam specimen

\section{RESULTS AND DISCUSSION}

Under the flexural test, three SCC beam specimens containing eggshells as partial cement substitutes were prepared and tested for failure. In addition, measurements on the optimal flexural strength were reported for SCC beam specimens, and the observation on cracking features was deliberated on the subsequent sub-topics.

\section{Flexural Strength}

The flexural test performed on SCC beam specimens was used to assess the load-deflections curve relationship, types and patterns of cracks on beam specimens, and the initial beams crack width diameter. The result of the load versus deflection relationship of SCC beam specimens was depicted in Figures 7 to 9.

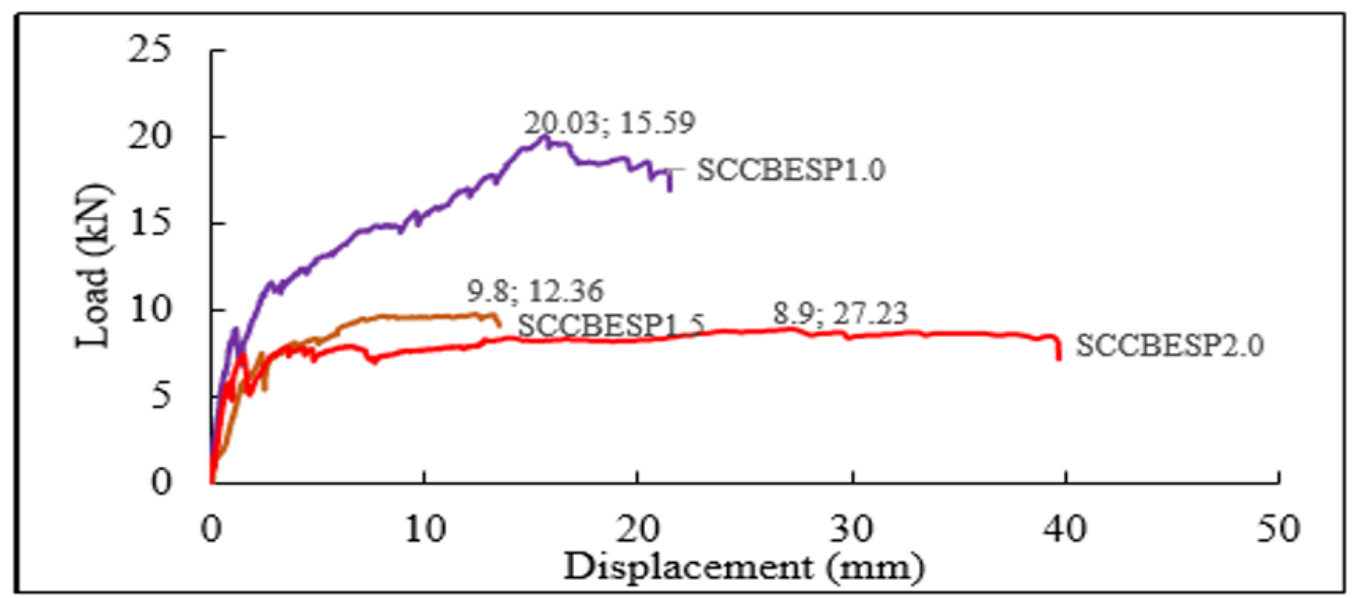

Figure 7. Applied load-mid-span deflection curves of SCC beam specimens (LVDT 1) 


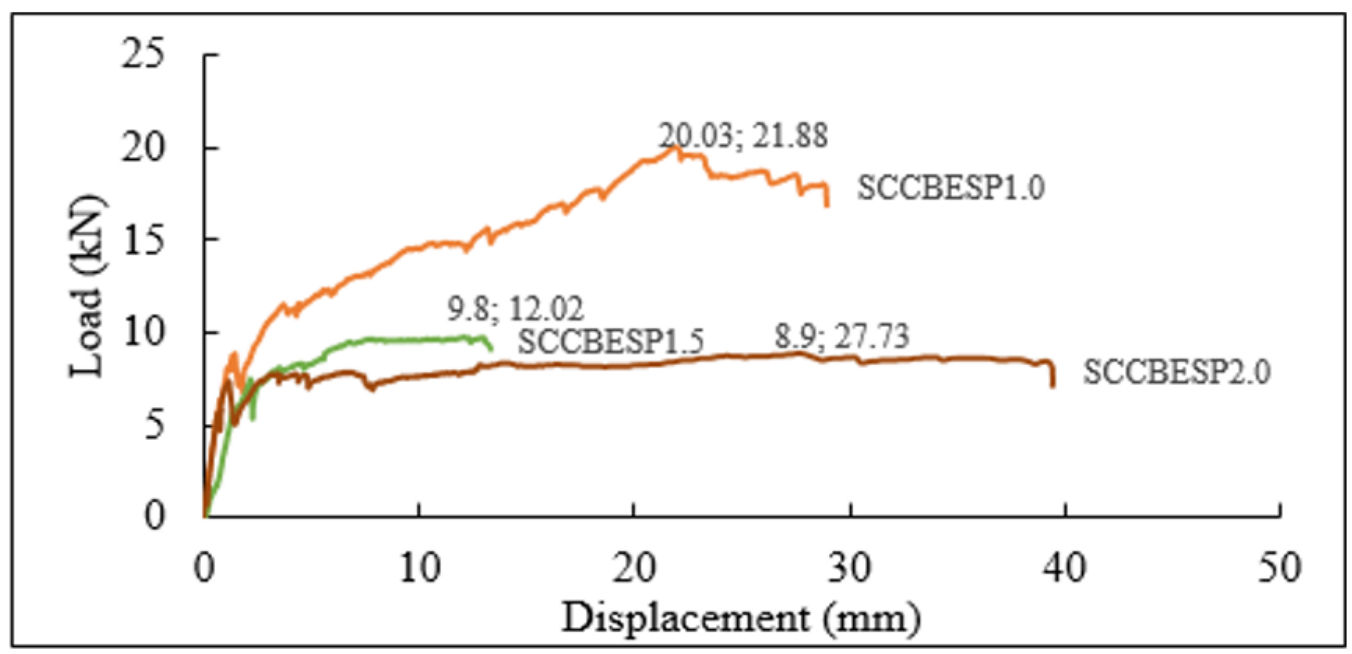

Figure 8. Applied load-mid-span deflection curves of SCC beam specimens (LVDT 2)

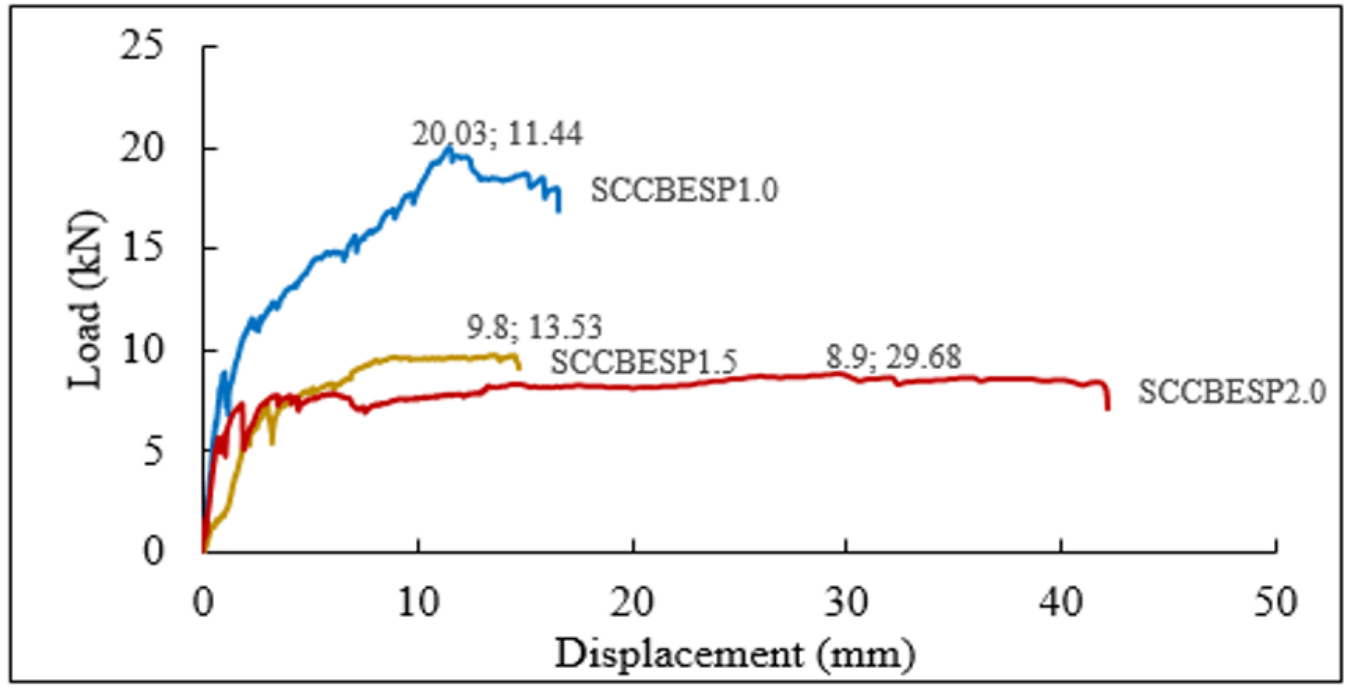

Figure 9. Applied load-mid-span deflection curves of SCC beam specimens (LVDT 3)

The relationship between load and deflection for SCCBESP1.0, SCCBESP1.5 and SCCESP2.0 of LVDT 1 (mid-span), LVDT 2 and LVDT 3 are presented in Figures 7 to 9 , respectively. Typically, all load-deflection curves display a linear elastic pattern before switching to plastic. Nevertheless, the SCCBESP1.0 beam displayed higher failure loads $(20.03 \mathrm{kN})$ contrasted with SCCBESP1.5 $(9.8 \mathrm{kN})$ and SCCBECSP2.0 $(8.9 \mathrm{kN})$. Pertinently, the load-deflection curves for SCCBESP1.0 signify a nonlinear rise, while for SCCBESP1.5 and SCCBESP2.0, the curves seem to be almost flat in the plastic area before the beams have failed. It is noticed that with a lower $a / d$ ratio (or when loads have been put close to 
supports), the beam can retain a higher load with improved deflection control compared to SCCBESP2.0.

\section{Failure and Crack Behaviour}

The characteristics of the crack were delineated in Figure 10 ( $a, b$ and $c$ ) with regards to the results gained through experimental observations for three (3) SCC beams, namely SCCBESP1.0, SCCBESP2.0 and SCCBESP3.0.

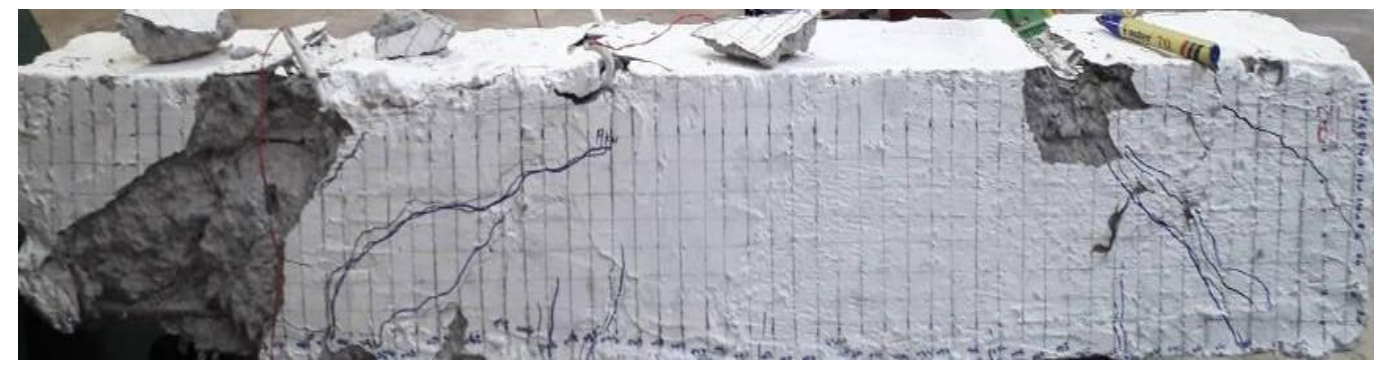

(a) $\operatorname{SCCBESP} 1.0(\mathrm{a}=160 \mathrm{~mm})$

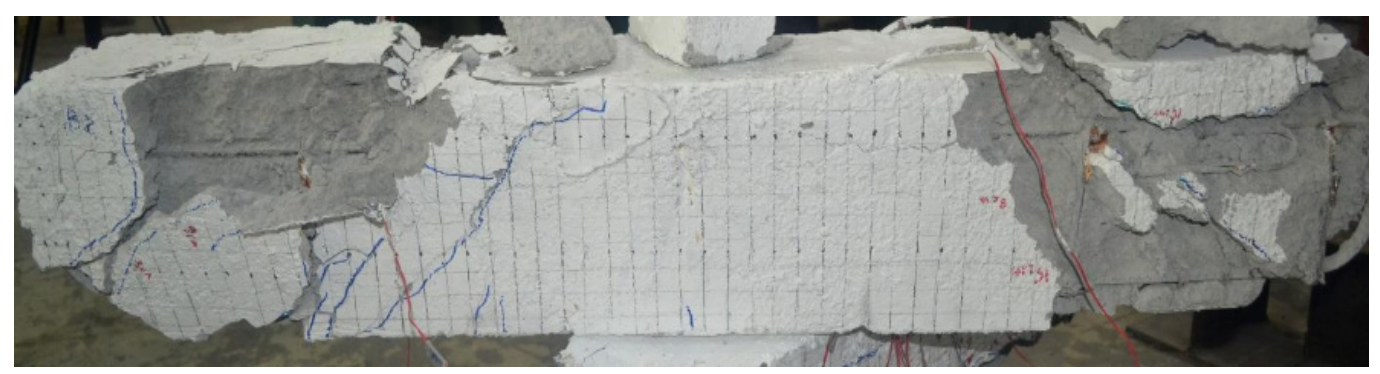

(b) SCCBESP2.0 $(\mathrm{a}=240 \mathrm{~mm})$

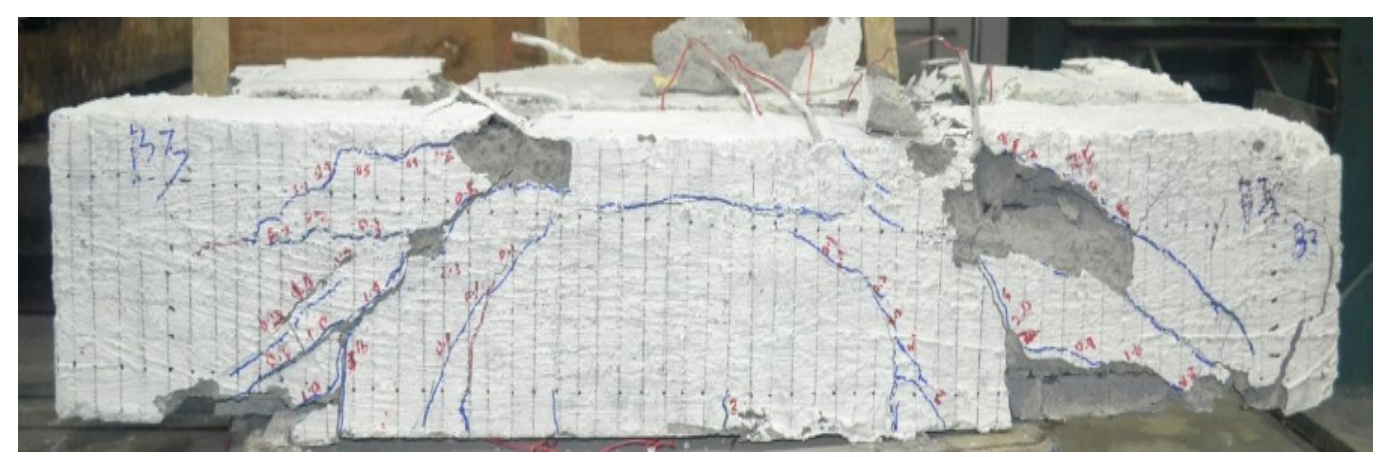

(c) SCCBESP3.0 $(\mathrm{a}=320 \mathrm{~mm})$

Figure 10. SCC beams crack features in flexural 
SCC beams with a wider range of cracks and cracks widths appeared to have emerged and were spotted at the support, and then spreads to the medium beam span as the $a / d$ ratio upsurges from 1.0 to 2.0, as presented in Figure 10. It may be because the SCC beam comprising ESP suffered significant deformations prior to failure, which led to the establishment of more and broader cracks. Therefore, each of the developed cracks in the SCC beams was examined to assess the characteristics and patterns of cracks. The SCC beams cracking behaviour are depicted in Figures 11 to 13.

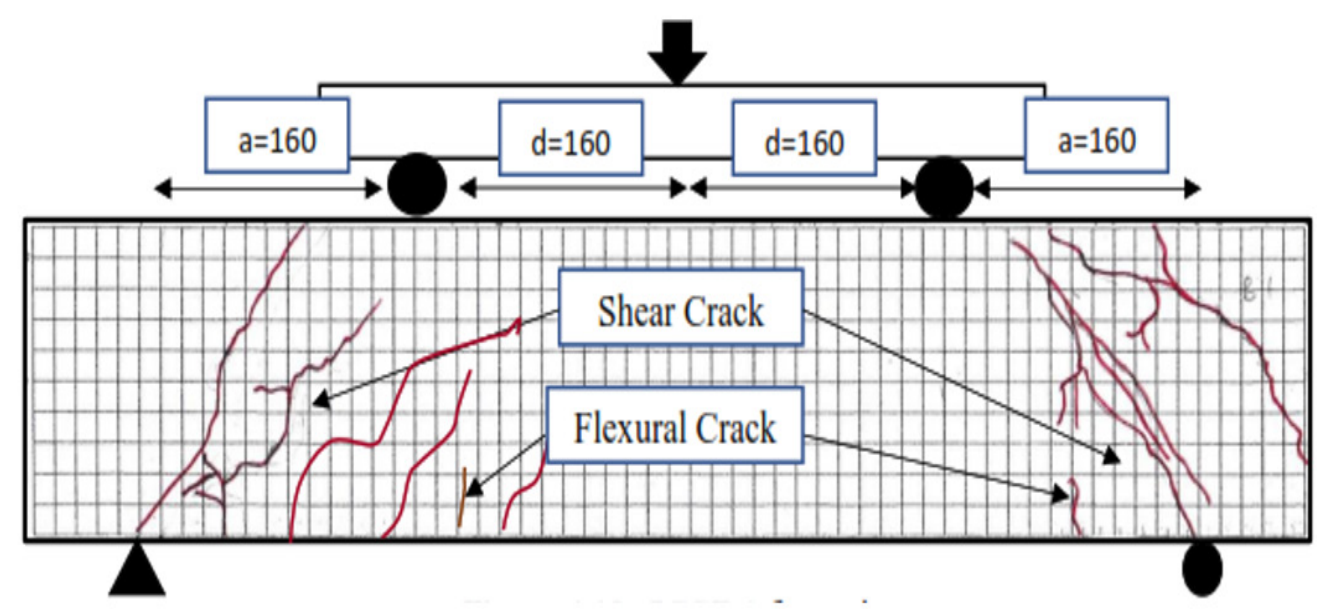

(a) Front observation

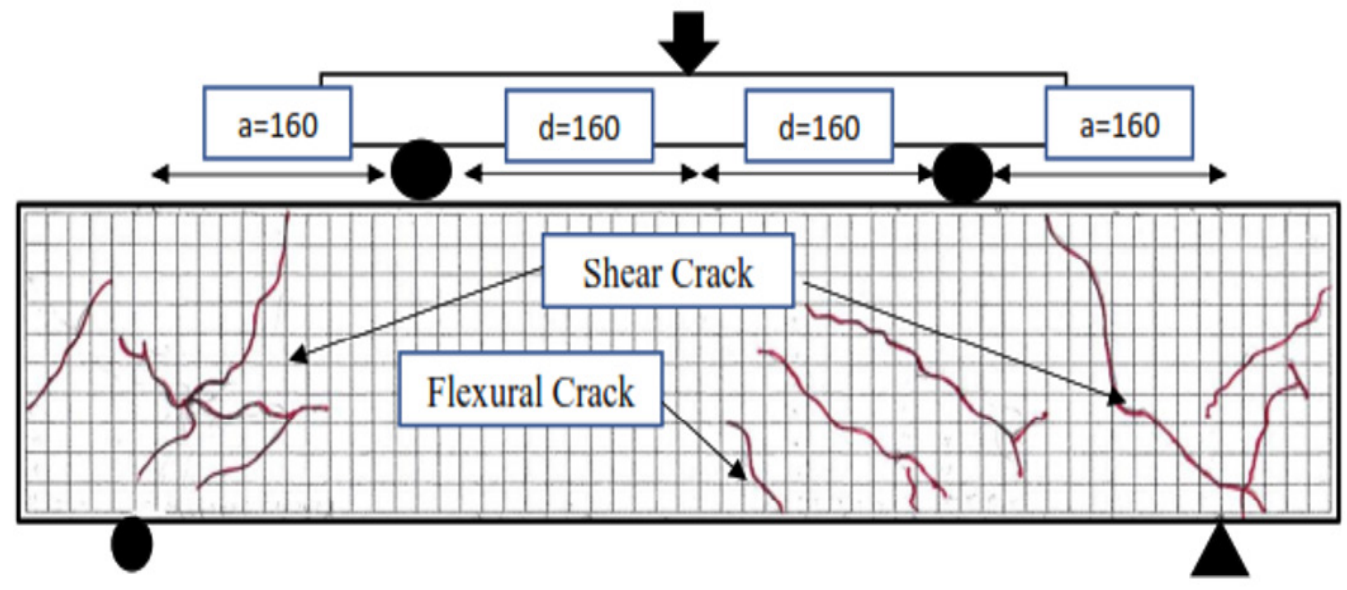

(b) Rear observation

Figure 11. Characteristics of cracks on SCC beams under flexural test (a=160mm) 


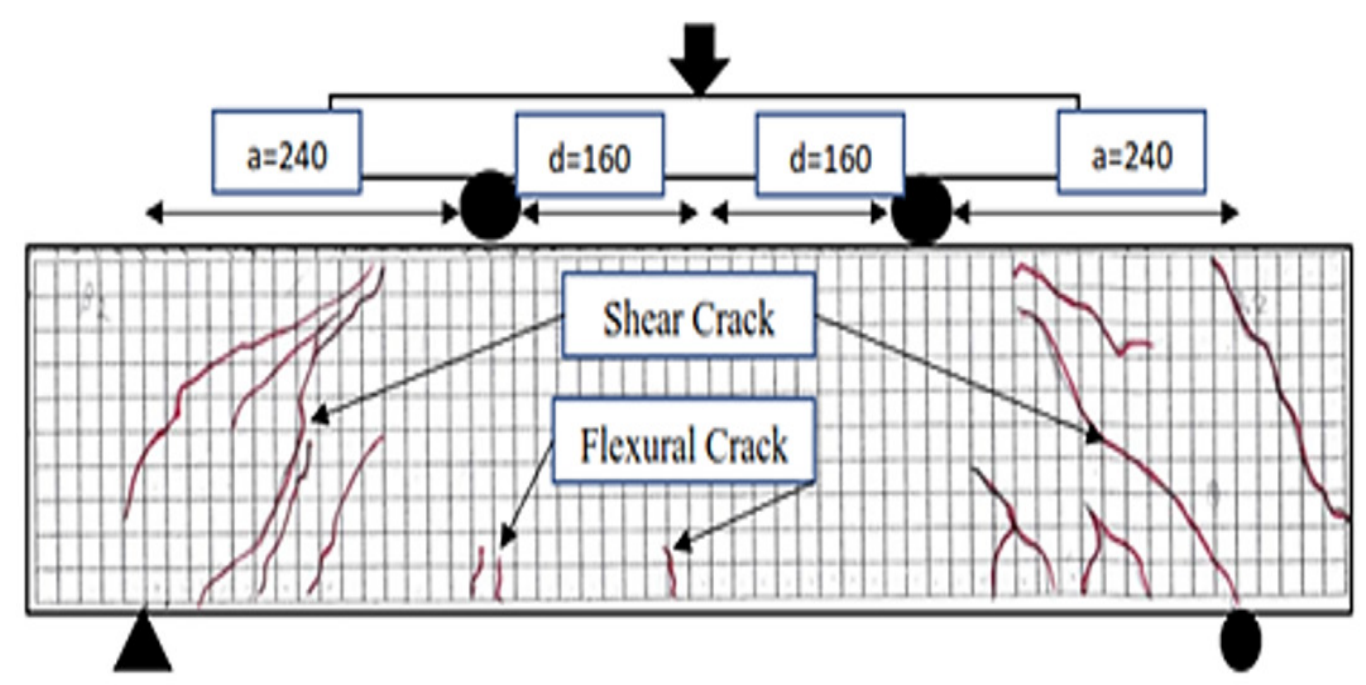

(a) Front observation

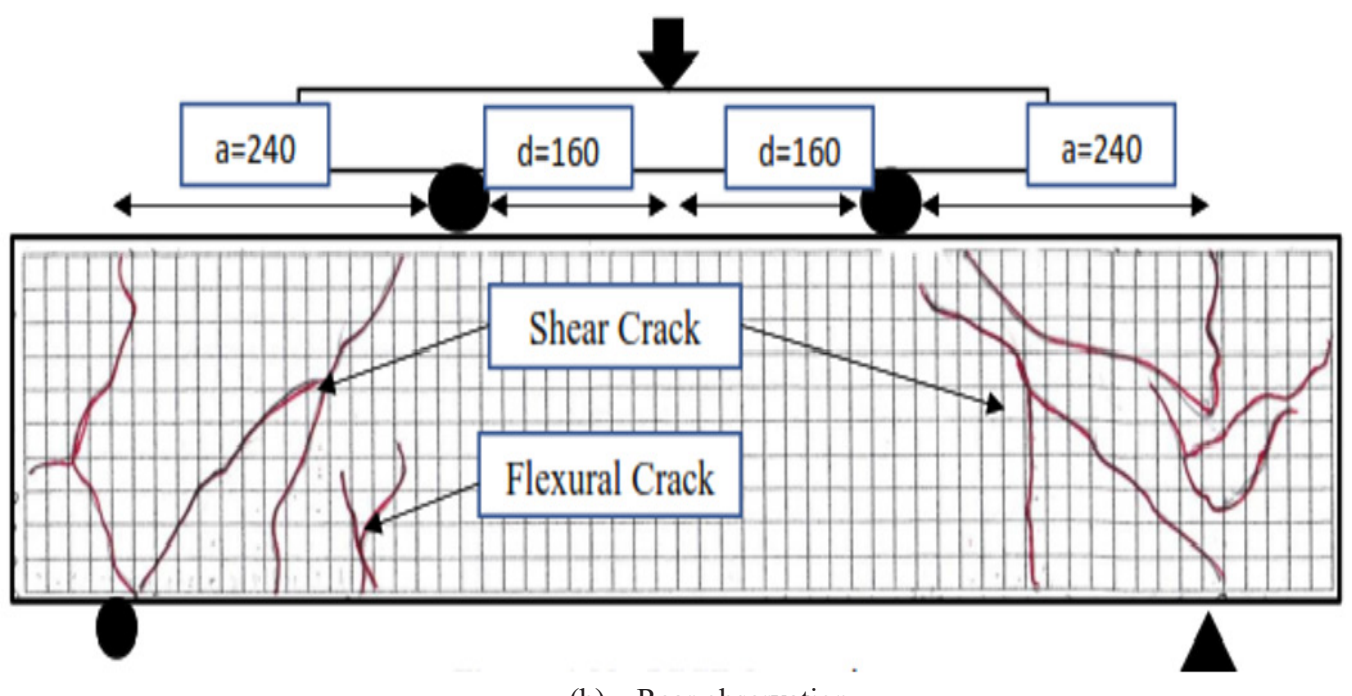

(b) Rear observation

Figure 12. Characteristics of cracks on SCC beams under flexural test $(\mathrm{a}=240 \mathrm{~mm})$

Shear cracks, flexural cracks, and shear-flexural cracks combination, as depicted in Figures 11 to 13, are the varieties of cracks observed for SCC beams. Shear cracks were found mostly at the support, while flexural cracks were noticed at the central part of the SCC beam span length. At quarter points along the SCC beam, shear cracks were detected (diagonal cracks). Afterwards, flexural fractures were formed vertically by enhancing the load, and cracks in the pattern of flexure-shear (inclined) started to emerge. Table 3 provides a comparative analysis of crack widths for all beam specimens tested 
with international standard Eurocode2. The present result revealed that the initial crack width for SCCBESP1.0 was recorded as $0.1 \mathrm{~mm}$. Meanwhile, for specimens designates as SCCBESP2.0 and SCCBESP3.0, the initial crack width was recorded as $0.1 \mathrm{~mm}$ and $0.1 \mathrm{~mm}$, respectively. Moreover, the ratio between both the experiments crack widths $w_{E}$ and theoretical crack control width $w_{T}$ (Eurocode2 (EN 1992-1-1, 2004)) for all beam specimens (SCCBESP1.0, SCCBESP2.0 and SCCBESP3.0) was recorded as 0.67, 0.33 and 0.33 , respectively.

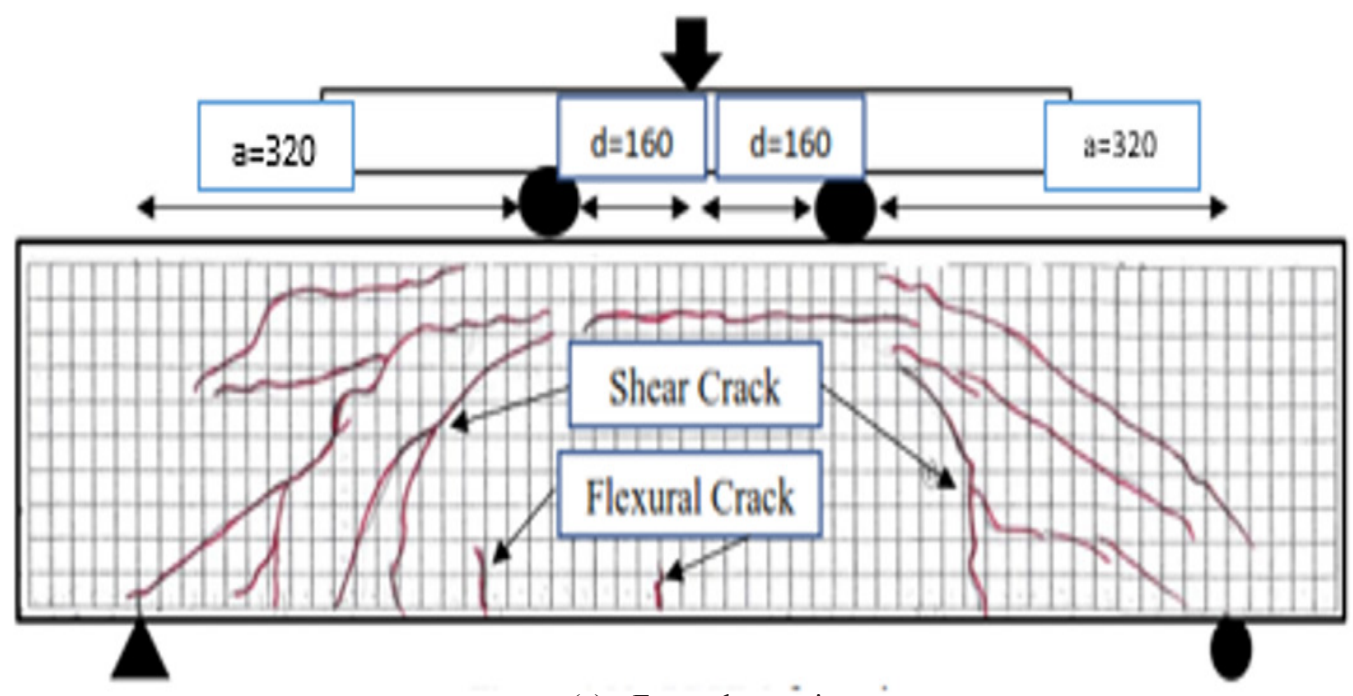

(a) Front observation

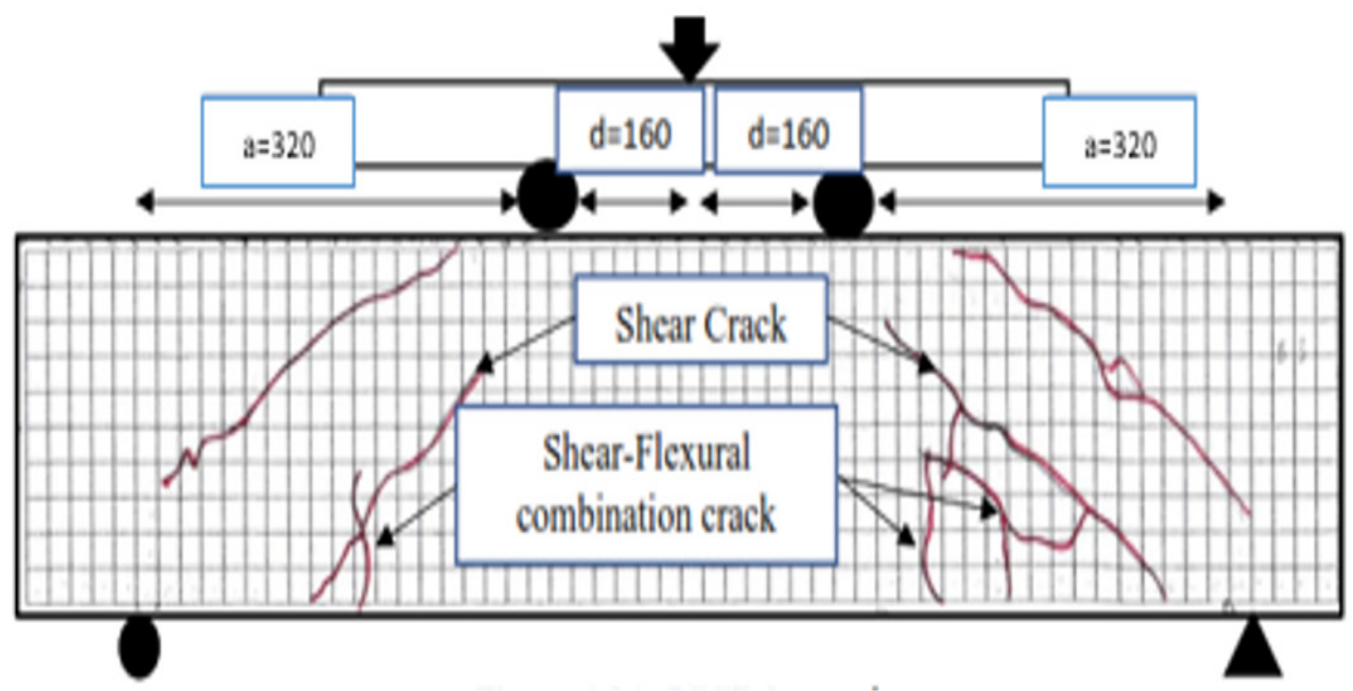

(b) Rear observation

Figure 13. Characteristics of cracks on SCC beams under flexural test $(\mathrm{a}=320 \mathrm{~mm})$ 
Table 3

Comparative analysis of the experimental and theoretical crack widths (Eurocode2)

\begin{tabular}{lccc}
\hline Mixture ID & $* w_{E}$ & $* w_{T}$ & $w_{E} / w_{T}$ \\
\hline $\operatorname{SCCBESP} 1.0(a / d=1.0)$ & 0.2 & $0.3-0.4$ & 0.67 \\
$\operatorname{SCCBESP} 2.0(a / d=1.5)$ & 0.1 & $0.3-0.4$ & 0.33 \\
$\operatorname{SCCBESP} 3.0(a / d=2.0)$ & 0.1 & $0.3-0.4$ & 0.33 \\
\hline
\end{tabular}

* $\mathrm{W}_{\mathrm{E}}$ denotes the experimental crack width $(\mathrm{mm})$

$\mathrm{W}_{\mathrm{T}}$ denotes the theoretical crack width $(\mathrm{mm})$

As portrayed in Table 3, the experimental crack widths $w_{E}$ fulfilled the maximum theoretical crack width $\mathrm{w}_{\mathrm{T}}(0.3 \mathrm{~mm}-0.4 \mathrm{~mm})$ quantified by Eurocode 2 .

\section{Correlation Among $a / d$ Ratio and Critical Crack Width (CDC)}

The critical diagonal crack, or delineated as CDC, was the significant crack that appeared when the beams underwent the load test and failed. Essentially, CDC occurred at the shear crack in which the initial crack took place. Therefore, the inclination angle of CDC regarding beam specimens longitudinal axis denotes as SCCBESP1.0, SCCBESP2.0, and SCCBESP3.0 was drawn as depicted in Figures 14 to 16.

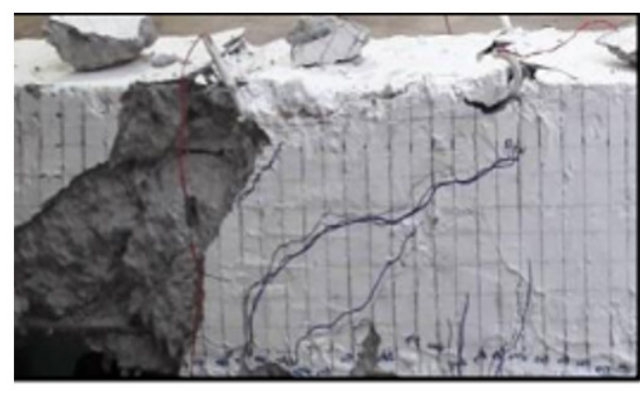

(a) Front view (Left)
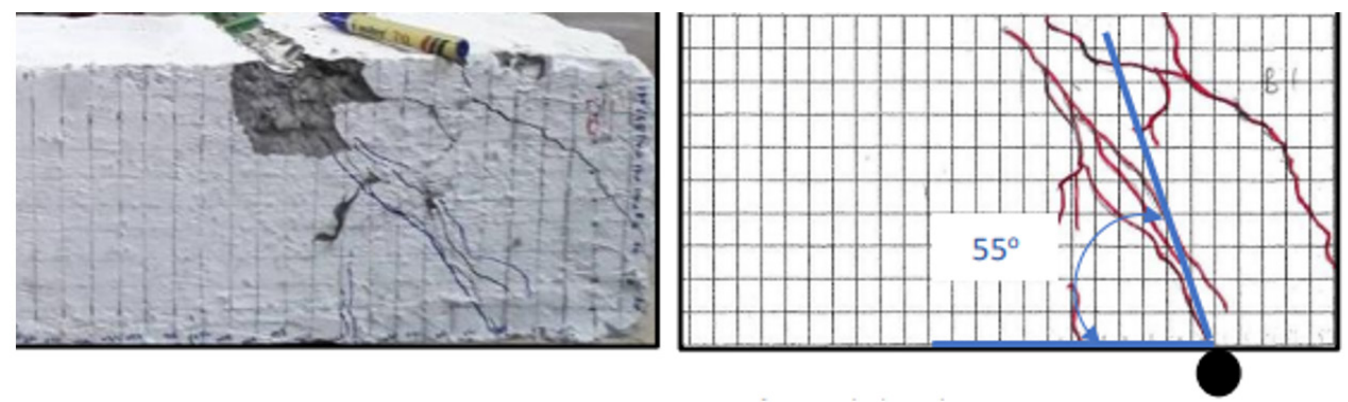

(b) Front view (Right) 

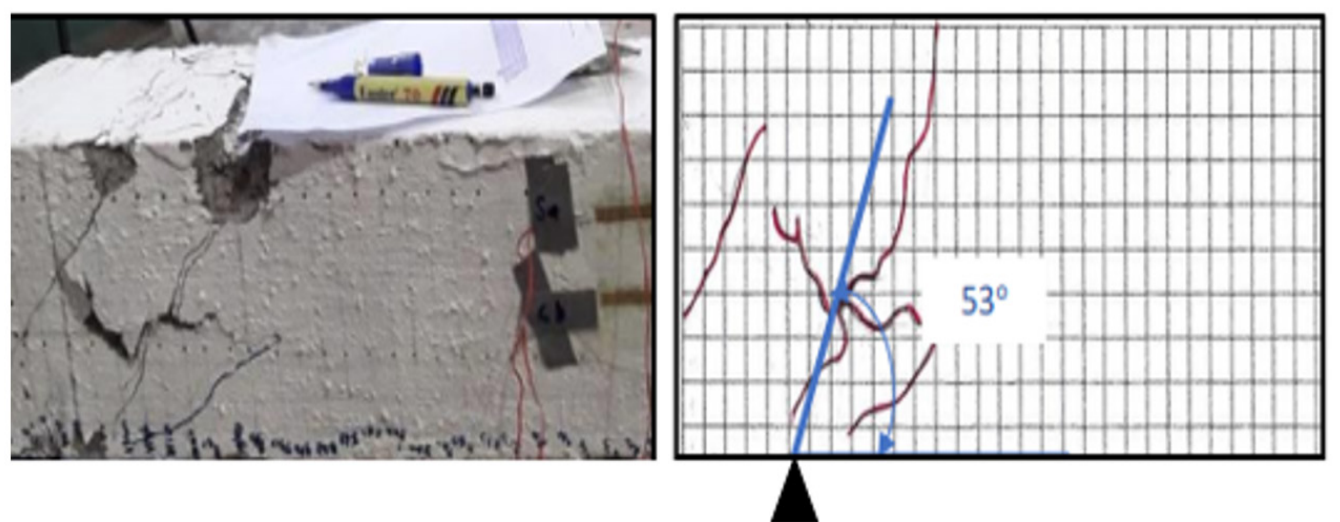

(c) Rear view (Left)
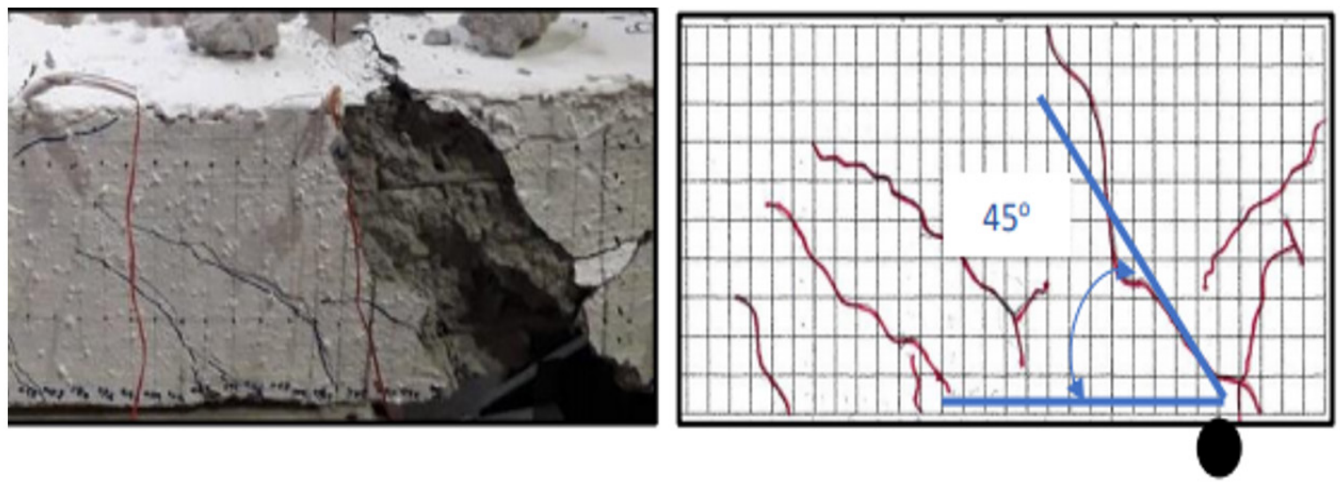

(d) Rear view (Right)

Figure 14. Critical crack width (CDC) of beam specimen (SCCBESP1.0)
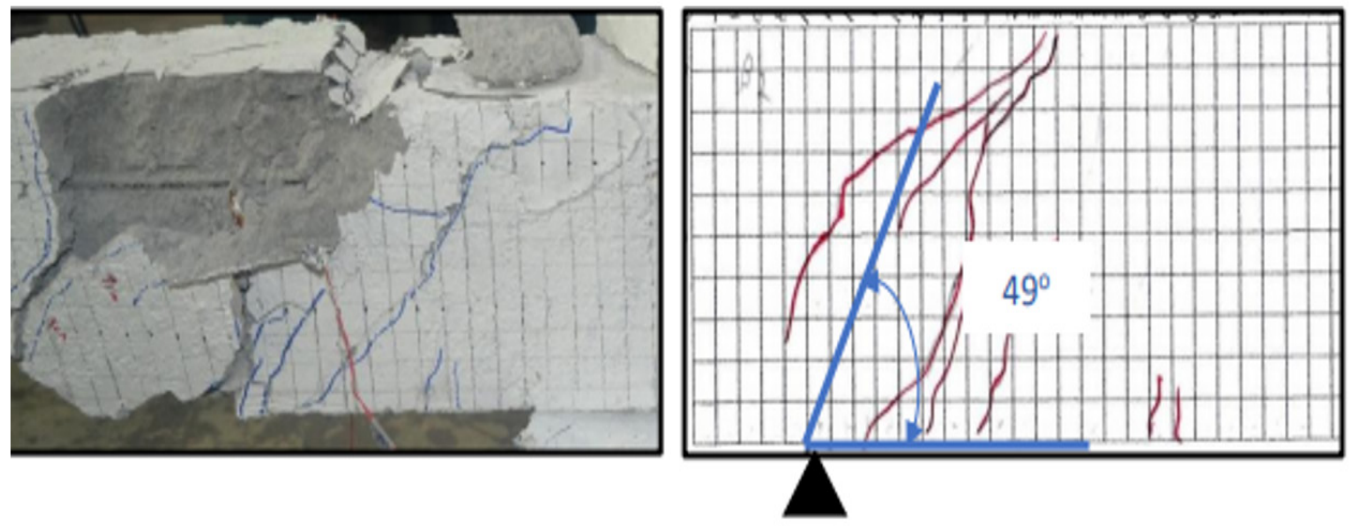

(a) Front view (Left) 

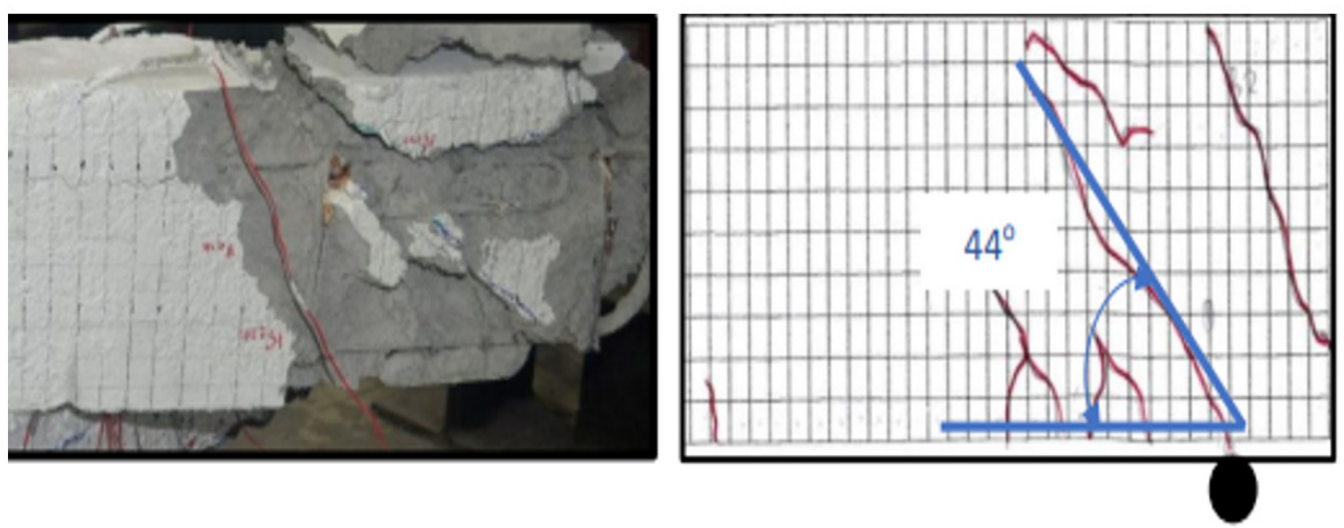

(b) Front view (Right)
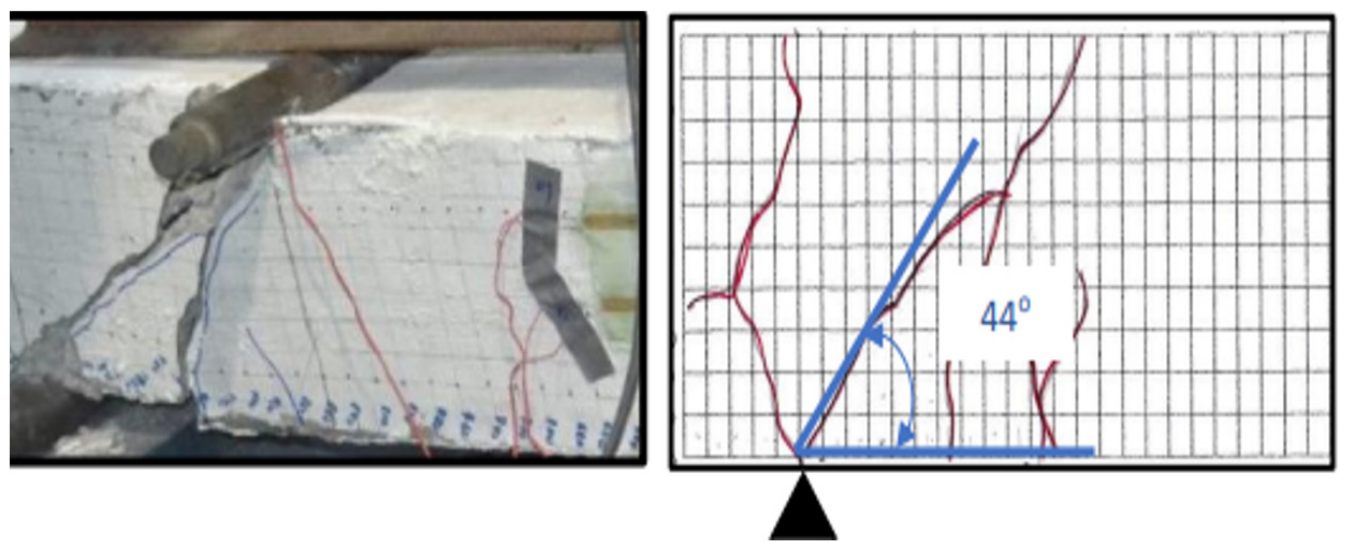

(c) Rear view (Left)
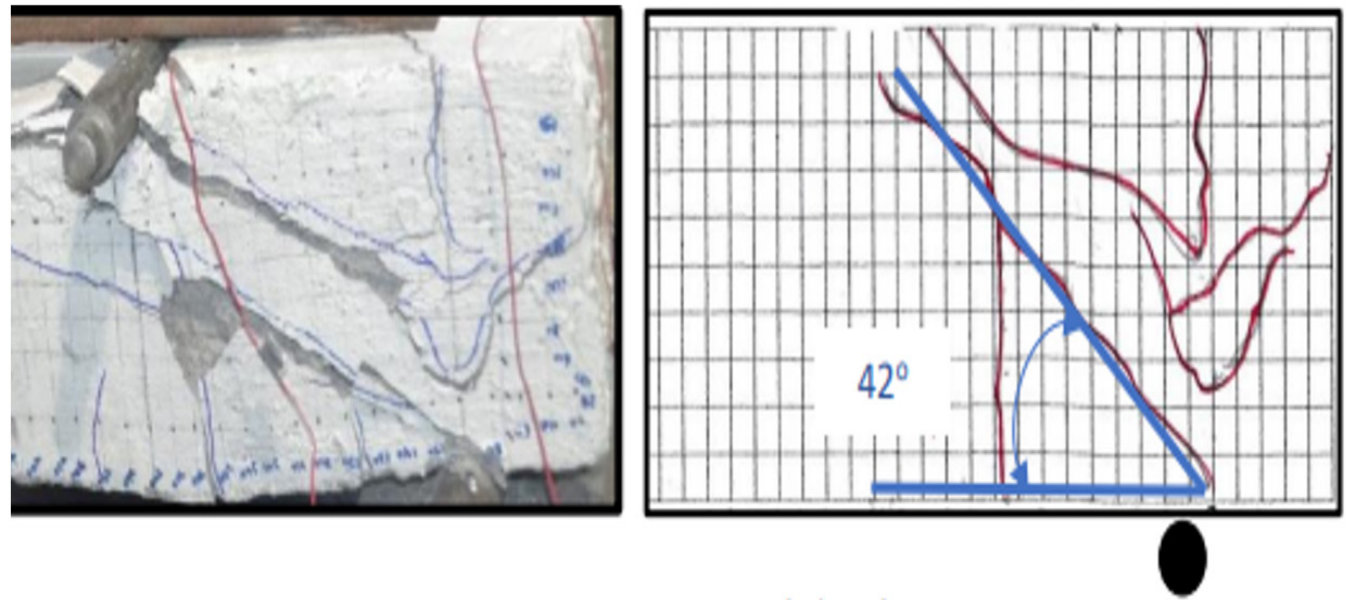

(d) Rear view (Right)

Figure 15. Critical crack width (CDC) of beam specimen (SCCBESP1.5) 


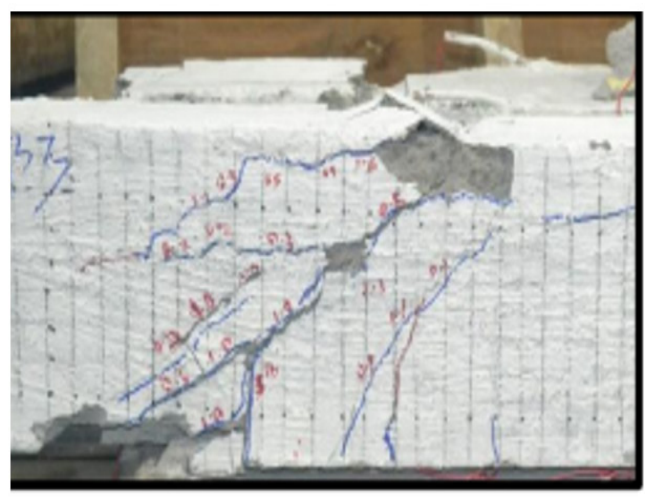

(a) Front view (Left)
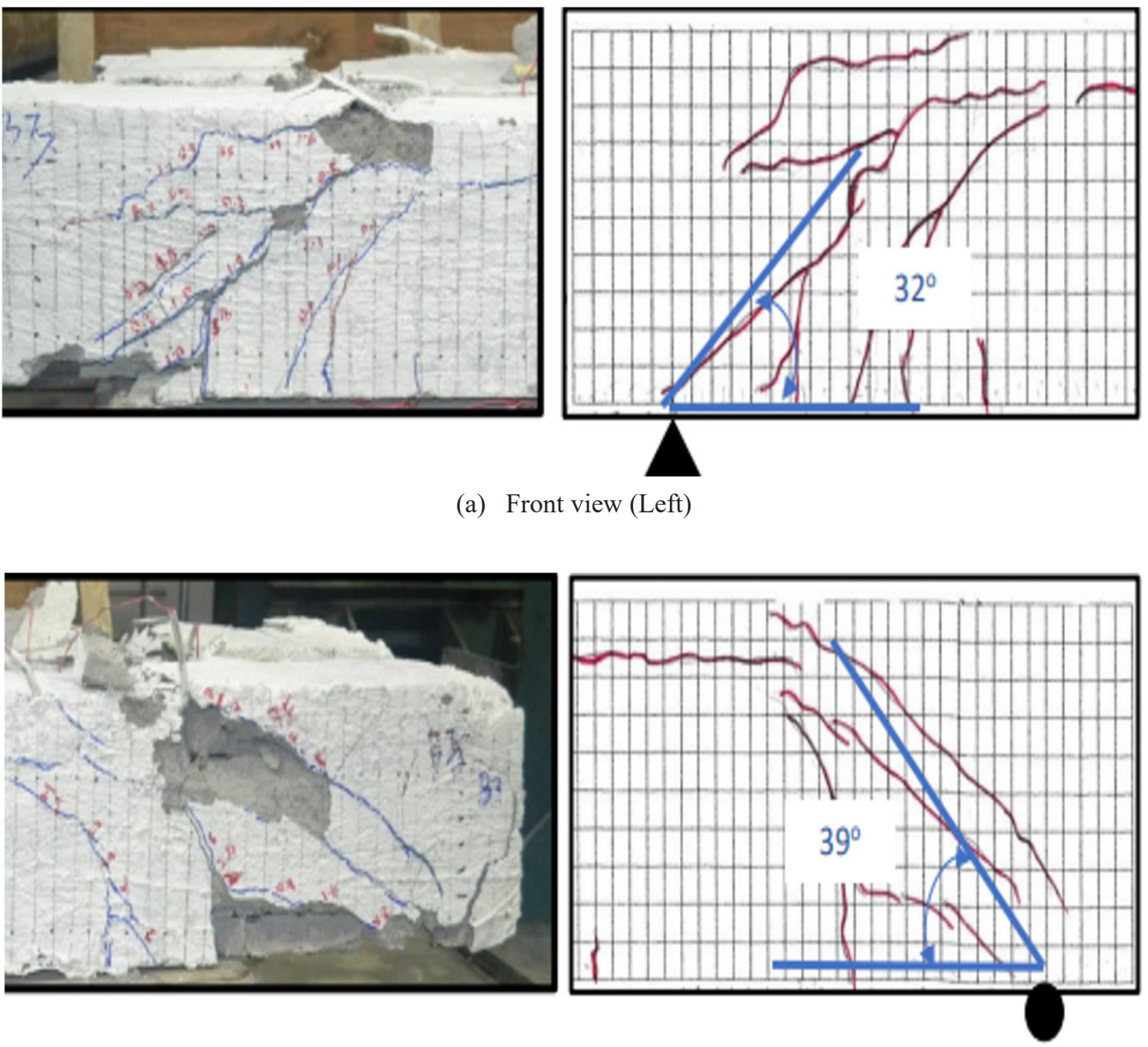

(b) Front view (Right)
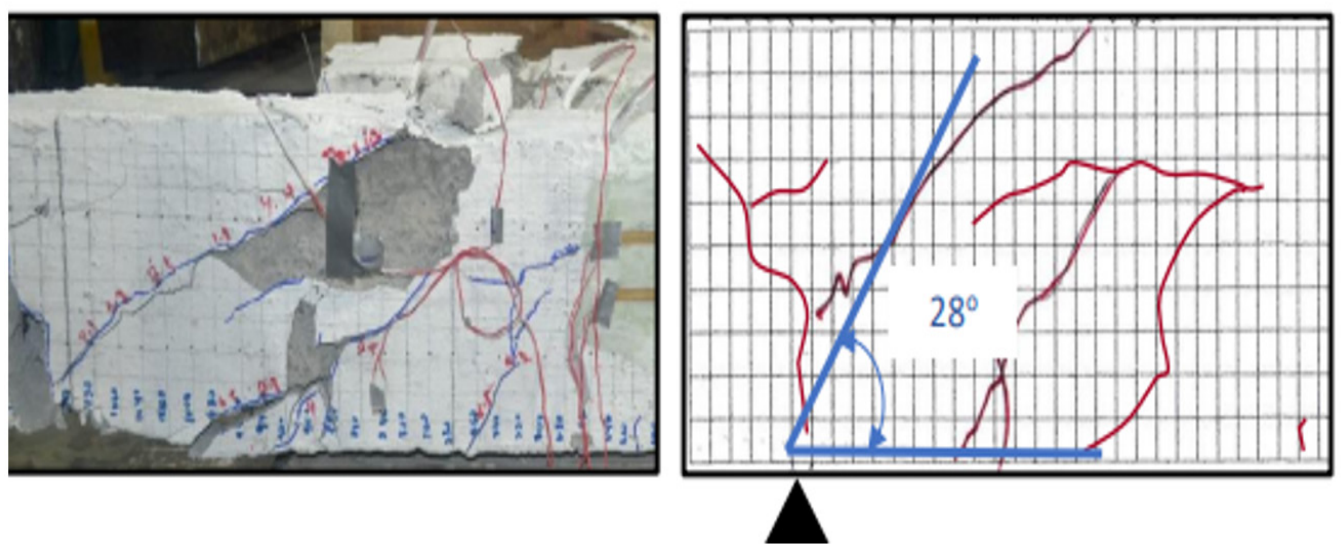

(c) Rear view (Left) 

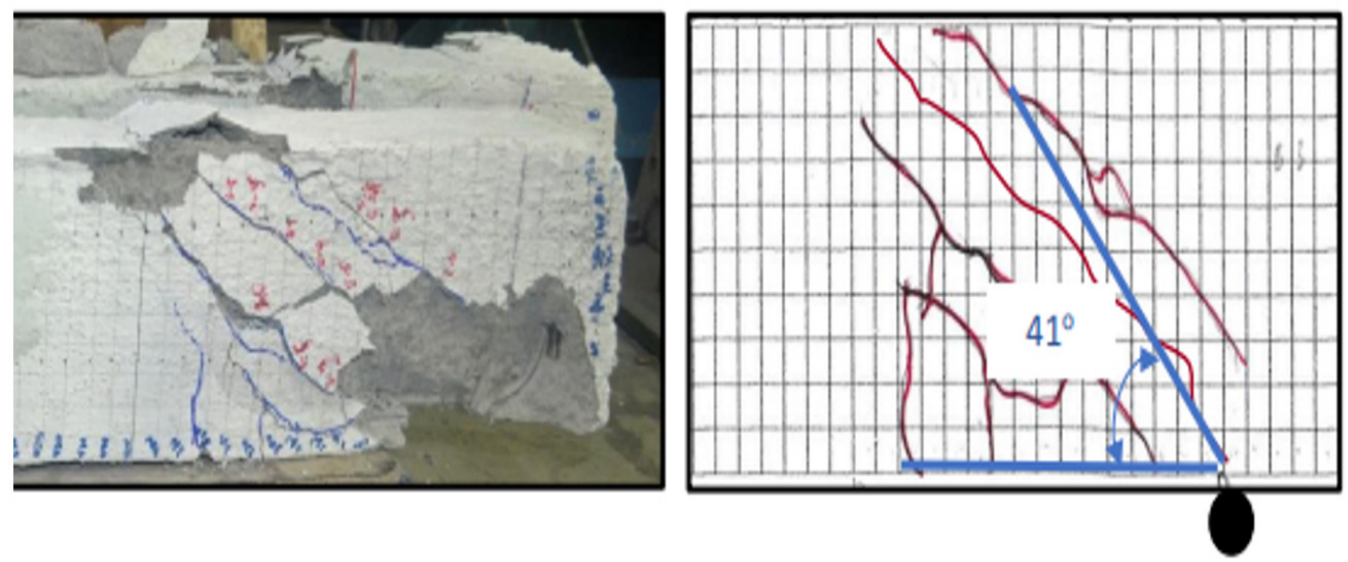

(d) Rear view (Right)

Figure 16. Critical crack width (CDC) of beam specimen (SCCBESP2.0)

The smallest critical diagonal crack (CDC) angle, as shown in Table 4 and detected from beam specimens, embodies as SCCBESP1.0, SCCBESP1.5, and SCCBESP2.0 was $28^{\circ}$ [located at the SCCBESP2.0 rear view (right)]. In comparison, the largest CDC angle was $55^{\circ}$ [located at the SCCBESP1.0 front view (left)]. Thus, the various types of cracks such as shear, flexural and combination of flexural-shear cracks caused a difference in angle between the front and rear views. With a mean value of 0.95 , a standard deviation (SD) of 0.04 and a coefficient of variation (C.O.V) of 4.99 per cent, the experimental CDC angle located at the rearview (right) of all beam specimens is seen to correlate closely to the theoretically envisaged by Eurocode2 (EN 1992-1-1, 2004).

Table 4

Comparative analysis of the experimental and theoretical crack angle (Eurocode2)

\begin{tabular}{|c|c|c|c|c|c|c|c|c|c|}
\hline \multirow[t]{2}{*}{$\begin{array}{l}\text { Specimen } \\
\text { designation }\end{array}$} & \multicolumn{4}{|c|}{$\begin{array}{l}\text { Inclination angle of } \mathrm{CDC} \text { with } \\
\text { regards to beam specimens } \\
\text { longitudinal axis, } \theta_{\mathrm{CR}}\left({ }^{\circ}\right)\end{array}$} & \multirow{2}{*}{$\begin{array}{l}\text { Theo. } \\
\text { crack } \\
\text { angle } \\
\theta_{\mathrm{EC}}\left({ }^{\circ}\right)\end{array}$} & \multicolumn{4}{|c|}{$\theta_{\mathrm{CR}} / \theta_{\mathrm{EC}}$} \\
\hline & $\begin{array}{l}\text { Front } \\
\text { view } \\
\text { (left) }\end{array}$ & $\begin{array}{l}\text { Front } \\
\text { view } \\
\text { (right) }\end{array}$ & $\begin{array}{l}\text { Rear } \\
\text { view } \\
\text { (left) }\end{array}$ & $\begin{array}{l}\text { Rear } \\
\text { view } \\
\text { (right) }\end{array}$ & & $\begin{array}{l}\text { Front } \\
\text { view } \\
\text { (left) }\end{array}$ & $\begin{array}{l}\text { Front } \\
\text { view } \\
\text { (right) }\end{array}$ & $\begin{array}{l}\text { Rear } \\
\text { view } \\
\text { (left) }\end{array}$ & $\begin{array}{l}\text { Rear } \\
\text { view } \\
\text { (right) }\end{array}$ \\
\hline SCCBESP1.0 & 55 & 55 & 53 & 45 & $22-45$ & 1.22 & 1.22 & 1.18 & 1.00 \\
\hline SCCBESP 1.5 & 49 & 44 & 44 & 42 & $22-45$ & 1.09 & 0.98 & 0.98 & 0.93 \\
\hline SCCBESP2.0 & 32 & 39 & 28 & 41 & $22-45$ & 0.71 & 0.87 & 0.62 & 0.91 \\
\hline \multicolumn{6}{|l|}{ Mean } & 1.01 & 1.02 & 0.93 & 0.95 \\
\hline \multicolumn{6}{|c|}{ Standard deviation (SD) } & 0.22 & 0.15 & 0.16 & 0.04 \\
\hline \multicolumn{6}{|c|}{ Coefficient of variation (C.O.V) (\%) } & 26.3 & 17.5 & 30.6 & 4.99 \\
\hline
\end{tabular}




\section{CONCLUSION}

The flexural behaviour and crack characteristics were assessed and observed, and the experimental outcomes were validated with the theoretical crack control value implied via Eurocode2 (EN 1992-1-1, 2004). The result of the study has directed to the subsequent conclusions:

1. The SCC beam can retain a higher load with enhanced deflection control when loads have been put near supports (lower a/d ratio).

2. On the SCC beam specimens, shear, flexural and shear-flexural cracks have been observed. Shear cracks were found mostly at the support, while flexural fractures were noticed at the centre of the beam span. At quarter points along the SCC beam, shear cracks were detected (diagonal cracks). Afterwards, cracks in the flexural shape developed vertically, and fractures in the form of flexure-shear (inclined) came into existence.

3. The crack width contour line was more toward the support when the a/d ratio dropped from 2.0 to 1.0. Nevertheless, once the SCC beam specimen was tested to failure subjected to a flexural test, the crack width contour line was detected more toward the central span of the SCC beam with a higher $a / d$ ratio.

4. The outcomes of all SCC beams measurements found that the initial value of experimental crack width was well below the $0.3 \mathrm{~mm}$ maximum crack control limit, as defined via Eurocode2 (EN 1992-1-1, 2004).

5. The experimental CDC angle located at the rearview (right) of all beam specimens has been seen to align closely to the theoretically proposed by Eurocode2 (EN 1992-1-1, 2004).

\section{ACKNOWLEDGMENTS}

The Ministry of Higher Education provided funding for the present work under the Fundamental Research Grant Scheme (FRGS) (600-IRMI/FRGS 5/3 (378/2019)). The authors are grateful to M. Fiqry Haziq Saharuddin for helping with the work of the laboratory. The authors also want to acknowledge the additional support of all technicians in the School of Civil Engineering laboratories, College of Engineering, Universiti Teknologi MARA (UiTM), Shah Alam in carrying out this work.

\section{REFERENCES}

ACI CODE-318-14. (2014). Building code requirements for structural concrete and commentary. American Concrete Institute.

Akinpelu, M. A., Odeyemi, S. O., Olafusi, O. S., \& Muhammed, F. Z. (2019). Evaluation of splitting tensile and compressive strength relationship of self-compacting concrete. Journal of King Saud University Engineering Sciences, 31(1), 19-25. https://doi.org/10.1016/j.jksues.2017.01.002 
Boel, V., Helincks, P., Desnerck, P., \& Schutter, G. D. (2010). Bond behaviour and shear capacity of selfcompacting concrete. Design, Production and Placement of Self-Consolidating Concrete, RILEM Bookseries, 1, 343-353. https://doi.org/https://doi.org/10.1007/978-90-481-9664-7_29

BS 1881-125:2013. (2013). Testing concrete Methods for mixing and sampling fresh concrete in the laboratory. NBS Enterprise Ltd.

Challagalli, R., \& Hiremath, G. S. (2017). Comparative study on fresh and hardened concrete properties of ternary blend self compacting concrete. International Journal of Advance Research, Ideas and Innovations in Technology, 3(5), 13-17.

Dinakar, P., Babu, K. G., \& Santhanam, M. (2008). Durability properties of high volume fly ash self compacting concretes. Cement and Concrete Composites, 30(10), 880-886. https://doi.org/10.1016/j. cemconcomp.2008.06.011

Dinakar, P., Reddy, M. K., \& Sharma, M. (2013). Behaviour of self compacting concrete using Portland pozzolana cement with different levels of fly ash. Materials \& Design, 46, 609-616. https://doi. org/10.1016/j.matdes.2012.11.015

Domone, P. L. (2007). A review of the hardened mechanical properties of self-compacting concrete. Cement and Concrete Composites, 29(1), 1-12. https://doi.org/10.1016/j.cemconcomp.2006.07.010

EPG. (2015). The European guidelines for self-compacting concrete specification production and use. European Project Group.

EN 1992-1-1. (2004). Eurocode 2: Design of concrete structures - Part 1-1: General rules and rules for buildings. European Committee for Standardization.

Faraj, R. H., Ali, H. F. H., Sherwani, A. F. H., Hassan, B. R., \& Karim, H. (2020). Use of recycled plastic in self-compacting concrete: A comprehensive review on fresh and mechanical properties. Journal of Building Engineering, 30, Article 101283. https://doi.org/10.1016/j.jobe.2020.101283

Harkouss, R. H., \& Hamad, B. S. (2015). Performance of high strength self-compacting concrete beams under different modes of failure. International Journal of Concrete Structures and Materials, 9(1), 69-88. https:// doi.org/10.1007/s40069-014-0088-x

Hassan, A. A. A., Hossain, K. M. A., \& Lachemi, M. (2008). Behavior of full-scale self-consolidating concrete beams in shear. Cement \& Concrete Composites, 30, 588-596. https://doi.org/10.1016/j. cemconcomp.2008.03.005

Karthick, J., Jeyanthi, I. R., \& Petchiyammal, M. (2014). Experimental study on usage of egg shell as partial replacement for sand in concrete. International Journal of Advanced Research in Education Technology, 1(1), 7-10.

Mahmod, M., Hanoon, A. N., \& Abed, H. J. (2018). Flexural behavior of self-compacting concrete beams strengthened with steel fiber reinforcement. Journal of Building Engineering, 16, 228-237. https://doi. org/10.1016/j.jobe.2018.01.006

Odaa, S. A., Hason, M. M., \& Sharba, A. A. K. (2021). Self-compacting concrete beams reinforced with steel fiber under flexural loads: A ductility index evaluation. Materials Today: Proceedings, 42, 2259-2267. https://doi.org/10.1016/j.matpr.2020.12.313 
Oh, C. L., Lee, S. W., \& Zain, M. R. M. (2019). Fresh properties and compressive strength of self-compacting concrete containing eggshells. Malaysian Construction Research Journal, 28(2), 1-10.

Okamura, H., \& Ouchi, M. (2003). Self-compacting concrete. Journal of Advanced Concrete Technology, 1(1), 5-15. https://doi.org/https://doi.org/10.3151/jact.1.5

Olowofoyeku, A. M., Ofuyatan, O. M., Oluwafemi, J., \& David, O. (2019). Effect of various types and sizes of aggregate on self-compacting concrete. IOP Conference Series: Materials Science and Engineering, 640, Article 012054. https://doi.org/10.1088/1757-899X/640/1/012054

Panda, K. C., \& Bal, P. K. (2013). Properties of self compacting concrete using recycled coarse aggregate. Procedia Engineering, 51, 159-164. https://doi.org/10.1016/j.proeng.2013.01.023

Parthasarathi, N., Prakash, M., \& Satyanarayanan, K. S. (2017). Experimental study on partial replacement of cement with eggshell powder and silica fume. Rasayan Journal of Chemistry, 10(2), 442-449. https:// doi.org/10.7324/RJC.2017.1021689

Safi, B., Saidi, M., Aboutaleb, D., \& Maallem, M. (2013). The use of plastic waste as fine aggregate in the selfcompacting mortars: Effect on physical and mechanical properties. Construction and Building Materials, 43, 436-442. https://doi.org/10.1016/j.conbuildmat.2013.02.049

Sharifi, Y. (2012). Structural performance of self-consolidating concrete used in reinforced concrete beams. KSCE Journal of Civil Engineering, 16(4), 618-626. https://doi.org/DOI 10.1007/s12205-012-1517-5

Siddique, R. (2011). Properties of self-compacting concrete containing class F fly ash. Materials \& Design, 32(3), 1501-1507. https://doi.org/10.1016/j.matdes.2010.08.043

Sonebi, M., Tamimi, A., \& Bartos, P. J. M. (2003). Performance and cracking behaviour of reinforced beams cast with self-compacting concrete. ACI Materials Journal, 100(6), 492-500.

Tang, W. C., Ryan, P. C., Cui, H. Z., \& Liao, W. (2016). Properties of self-compacting concrete with recycled coarse aggregate. Advances in Materials Science and Engineering, 2016, 1-11. https://doi. org/10.1155/2016/2761294

Tošić, N., Marinković, S., \& Ignjatović, I. (2016). A database on flexural and shear strength of reinforced recycled aggregate concrete beams and comparison to Eurocode 2 predictions. Construction and Building Materials, 127, 932-944. https://doi.org/https://doi.org/10.1016/j.conbuildmat.2016.10.058

Yerramala, A. (2014). Properties of concrete with eggshell powder as cement replacement. The Indian Concrete Journal, 88(10), 94-102. 